\title{
THE USE OF MONOCLONAL ANTIBODIES IN AUTOIMMUNITY TREATMENT
}

Merzlyak $E M^{1,2} \otimes$, Syrko DS ${ }^{2}$, Musatkina $E A^{2}$, Israelson $M^{1,2}$

${ }^{1}$ Shemyakin-Ovchinnikov Institute of Bioorganic Chemistry, RAS, Moscow

${ }^{2}$ Research Institute of Translational Medicine,

Pirogov Russian National Research Medical University, Moscow

Recently, monoclonal antibodies (MA) have gained popularity as therapeutic agents for the treatment of autoimmune disorders. These antibodies target proinflammatory cytokines, as well as $\mathrm{T}$ and $\mathrm{B}$ cells potentially involved in the pathogenesis of such conditions. In the present work we attempt to give a systematic description of available therapeutic MA, highlight their key mechanisms of action and pinpoint their adverse effects. We believe that MA that are capable of recognizing and eliminating pathogenic T- and B-cell clones hold the most promise for medical application as biologics. Detection and identification of autoreactive lymphocyte clones is one of the most serious challenges of contemporary medicine.

Keywords: autoimmune disorders, biologics, therapeutic antibodies for autoimmunity treatment, mechanism of action of monoclonal antibodies

Funding: this work was supported by the Ministry of Science and Higher Education of the Russian Federation (ID RFMEFI60716X0158).

$\triangle$ Correspondence should be addressed: Ekaterina M. Merzlyak

Miklouho-Maclay, 16/10, Moscow, 117997; ekaterin99@mail.ru

Received: 06.12.2018 Accepted: 20.12.2018

DOI: $10.24075 /$ brsmu.2018.094

\section{ИСПОЛЬЗОВАНИЕ МОНОКЛОНАЛЬНЫХ АНТИТЕЛ ДЛЯ ТЕРАПИИ АУТОИММУННЫХ ЗАБОЛЕВАНИЙ}

\author{
Е. М. Мерзляк ${ }^{1,2} \bowtie$, Д. С. Сыркоㄱ, Е. А. Мусаткина², М. Израельсон ${ }^{1,2}$ \\ ${ }^{1}$ Институт биоорганической химии имени М. М. Шемякина и Ю. А. Овчинникова Российской академии наук, Москва \\ ${ }^{2}$ Научно-исследовательский институт трансляционной медицины, \\ Российский национальный исследовательский медицинский университет имени Н. И. Пирогова, Москва
}

\begin{abstract}
В последнее время в терапии аутоиммунных заболеваний стали активно применять моноклональные антитела (МА). Мишенью этих антител служат провоспалительные цитокины и собственно Т- и В-клетки, потенциально участвующие в патогенезе заболевания. В данной статье сделана попытка систематизировать используемые препараты и привести основные механизмы, лежащие в основе такого рода терапии, описаны нежелательные побочные действия. Потенциальными путями и перспективами развития биологиксов в лечении аутоиммунных заболеваний, по нашему мнению, являются МА, которые узнают и элиминируют клоны Т- и В-клеток, обусловливающие патогенез аутоиммунного заболевания. Поиск аутореактивных клонов является одной из сложных и актуальных задач современной биомедицины.
\end{abstract}

Ключевые слова: аутоиммунные заболевания, биологиксы, терапевтические антитела для лечения аутоиммунных заболеваний, механизм действия моноклональных антител

Финансирование: работа выполнена при поддержке Минобрнауки России (идентификатор соглашения RFMEFI60716X0158).

$\bigotimes$ Для корреспонденции: Екатерина Марковна Мерзляк

ул. Миклухо-Маклая, д. 16/10, г. Москва, 117997; ekaterin99@mail.ru

Статья получена: 06.12.2018 Статья принята к печати: 20.12.2018

DOI: 10.24075/vrgmu.2018.094

As we broaden our knowledge of the mechanisms underlying the adaptive immunity, we learn to identify its malfunctioning elements posing a risk of autoimmune disorders. The latter encompass an extensive array of pathologies affecting almost all body tissues. The pathogenesis of these disorders is linked to the production of autoimmune antibodies and proliferation of effector T-cell clones that recognize self-antigens and therefore provoke inflammation both locally and systemically. In their anergic (self-tolerant) state, autoreactive T-cells have also been found in the bloodstream of healthy donors [1] where they are controlled by regulatory $T$ cells (Tregs). The aberrant concentrations and abnormal functional activity of Tregs are among the possible causes of inflammation accompanying autoimmune disorders.

Current approaches to treating autoimmunity are based on the suppression of the immune system by therapeutic agents that directly or indirectly mitigate inflammation (see the Figure). This article looks at therapies for autoimmune diseases that involve the use of monoclonal antibodies (MA). Such MA, as well as other genetically engineered pharmaceutical agents, are referred to as biologics in the literature published in English. Some MA have already been proved effective in managing autoimmune conditions; some are currently undergoing clinical trials.

Therapeutic MA considerably vary in terms of their mechanism of action. They can bind a soluble ligand or a receptor on the membrane of a target cell thereby blocking the interaction between the receptor and the ligand, modulating the signal from the receptor or triggering apoptosis (Fig).

The mechanisms underlying the depletion of a target cell population by MA are diverse. Depletion mediated by the Fc fragment can induce apoptosis of the target cell, lead to cell 
death via antibody- or complementary-dependent cellular cytotoxicity (ADCC/CDC) pathways, and provoke antigendependent phagocytosis. The mechanisms activated by the blockade of surface costimulatory receptors are fundamentally different. They suppress the signal produced in response to antigen-induced stimulation or reprogram effector $T$ cells into Tregs.

Therapeutic antibodies causing a decline in the levels of anti-inflammatory cytokines (IFNy, TNF, IL17, and others) or blocking cytokine receptors can only bring temporary remission depending on their clearance rate. We think that approaches based on the depletion of lymphocyte subpopulations enriched in autoreactive $T$ cells are the most promising because they allow us to eliminate the cause of an autoimmune disease. Another interesting therapeutic strategy is based on the functional activation of regulatory $T$ cells in order to boost the expression of inhibitory cytokines, such as IL10.

\section{An overview of the structure of therapeutic antibodies and their application}

In the past few years, the list of therapeutic antibodies has been expanded considerably to comprise drugs with selective mechanisms of action used in disease modifying therapies (DMT). The US Food and Drug Administration (FDA) has approved about $40 \mathrm{MA}$ for treating various diseases including those of autoimmune nature.

As a rule, the primary products of MA synthesis require further optimization. The optimization strategies include modification of the Fc fragment aimed to extend the half-life of the obtained antibody; humanization by altering the amino acid sequence (this ensures the similarity of the synthetic structure to human antibodies and therefore reduces the immunogenicity of the drug); the use of special cell lines for antibody synthesis deficient in glycosylation enzymes, which helps to enhance the cytotoxicity of the end product. The cytotoxicity of nonfucosylated therapeutic antibodies is 500-1,000 times higher than that of the same antibodies with a high degree of glycosylation [2]. Recently, there have been proposals to introduce modifications to the Fc-fragment to avoid a wide range of adverse effects caused by inflammatory cytokines that are released in response to the massive death of effector cells that accompanies the use of therapeutic antibodies against surface markers found in many cell types.

\section{Monoclonal antibodies against cytokines and inflammatory factors}

The first MA approved in 2002 by FDA for the treatment of inflammatory diseases (mostly autoimmune) were antiTNF (tumor necrosis factor) antibodies. Recently, the list of therapeutic targets has been upgraded with a number of cytokines, including IL1, IL6, IL12, IL15, IL17, IL18, and IL23, associated with autoimmune pathology. The efficacy of the MA designed to fight various autoimmune disorders has been discussed in a few review articles [3, 4].

TNF is one of the primary inducers of inflammation in the cytokine cascade; therefore, its inhibitors can cause nonspecific inflammation in patients suffering from autoimmune disorders, such as rheumatoid arthritis or RA, ankylosing spondylitis, psoriasis, Crohn's disease, etc. Today, 4 MA against TNF are available clinically: infliximab, golimumab, certolizumab, and adalimumab. They are different in their humanization degree and the site they target. These drugs are widely used to manage rheumatoid disorders of autoimmune nature, including ankylosing spondylitis. TNF inhibitors slow down the progression of this disease but cannot prevent it from happening. However, not every patient responds to anti-TNF therapy. For example, one-third of patients with RA do not show any improvement when treated with TNF inhibitors. No therapeutic effect is also observed in patients with multiple sclerosis.

Unfortunately, the use of anti-TNF MA contributes to the risk of cancer and infection. In addition, TNF blockade does not cause any decline in IL1 implicated in cartilage degradation and joint erosion, which was demonstrated in mice with experimental RA [5].

Proinflammatory IL1 is another therapeutic target. We still think, though, that unlike anakinra (the antagonist of the IL1 receptor), MA against IL1 may not find wide application in clinical practice. For example, an anti-IL1 $\beta$ drug gevokizumab has proved ineffective against noninfectious uveitis (the symptom of Behcet's disease). Another fully human anti-IL1 $\beta$ antibody (IgG1, canakinumab) has recently completed a phase III clinical trial [6]. Although it was able to induce therapeutic response in

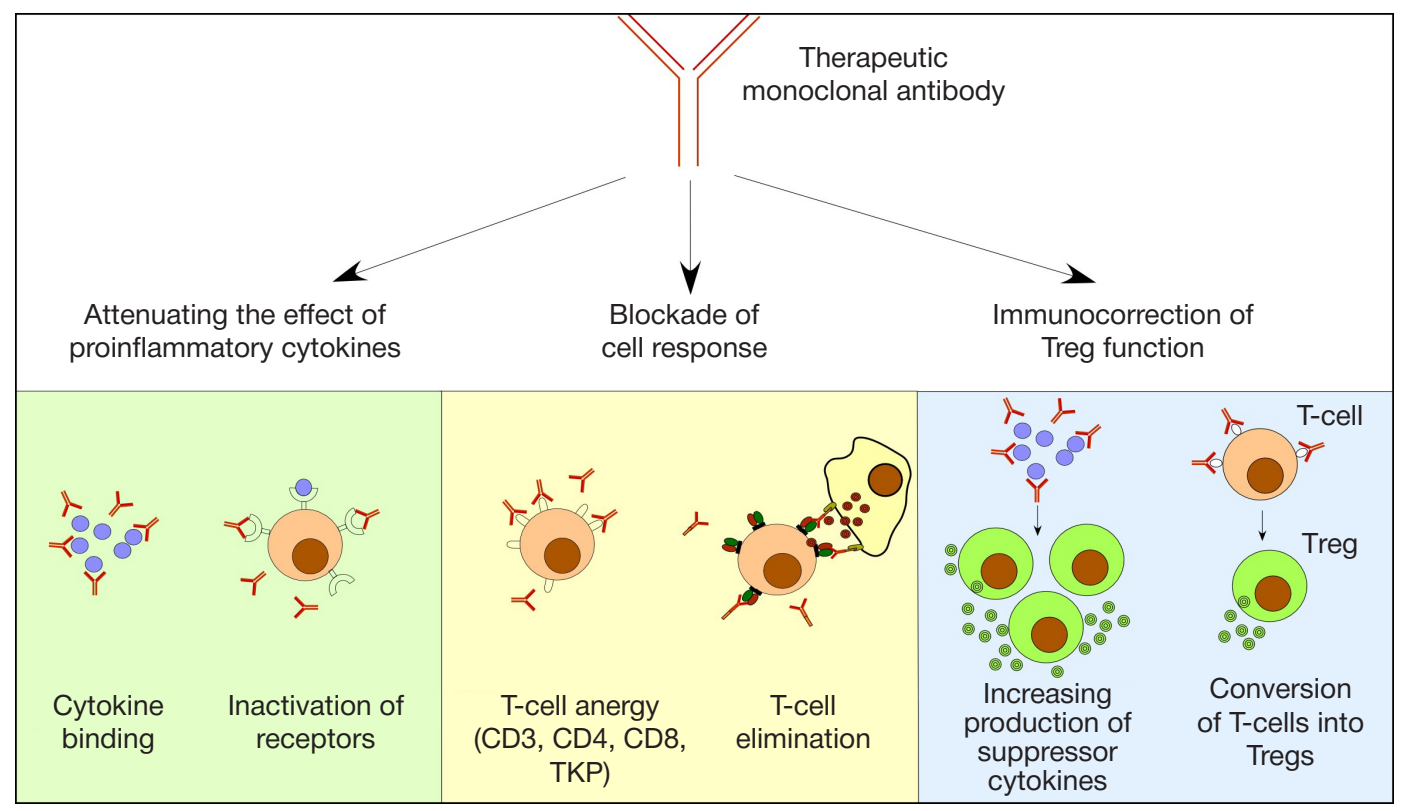

Monoclonal antibody treatment approaches for autoimmune disorders 
less than half of patients with RA and juvenile idiopathic arthritis (JIA) [7], it was still approved by FDA for the treatment of JIA and the cryopyrin-associated periodic syndrome (CAPS). Sustained remission was observed in $97 \%$ of patients with CAPS after a single dose of the drug; the adverse reactions were very mild $[8,9]$.

Another effective strategy for treating autoimmune disorders relies on the blockade of cytokines involved in the activation or differentiation of Th1- and Th17-cell populations associated with the pathogenesis of many autoimmune diseases. IL6 is an example of such proinflammatory factors that together with IL23 and TGF $\beta$ triggers differentiation of naïve CD4+-lymphocytes into Th17 cells [10]. Normally, Th17 cells participate in the immune response to bacterial and fungal infections. Hyperactive Th17 excessively produce IL17, GM-CSF, and IL21, promoting inflammation. The Th17/Tregs imbalance is observed in systemic lupus erythematosus (SLE), in the peripheral blood of patients with RA, at inflammation sites in patients with JIA, type 1 diabetes and Crohn's disease [11, 12].

One of the most effective drugs capable of inhibiting IL6 is tocilizumab (IgG1). It is a monoclonal antibody against the $\beta$-chain of the IL6 receptor that competes for this receptor preventing its binding to IL6. The drug has been proved safe and highly effective for the treatment of RA and JIA. The same level of efficacy has been demonstrated by olokizumab (a humanized antibody against IL6) that successfully completed a phase II clinical trial in 2017.

IL6 blockade by tocilizumab leads to an increase in the proportion of Tregs in the population of $\mathrm{CD}^{+}{ }^{+}$-cells both in mice with experimental EAE and patients with RA. This correlates with marked remission observed in such patients [13]. The therapeutic effect of these MA against IL6 relies on the methylation of the Foxp3 promoter induced by IL6, which leads to a decline in the functional activity of Tregs [14]. IL6 plays an important role in the immune response to bacterial infection in healthy individuals. It also exhibits protective properties in patients with liver/neural tissue injuries. It should be born in mind, though, that the prolonged intake of MA against IL6 can increase sensitivity to bacterial and viral infections and poses a risk of death in people with liver cirrhosis and strokes.

The blockade of interleukins or their receptors by MA can have a better therapeutic effect than methotrexate-based treatment or the use of other immunosuppressive drugs. Sadly, it is associated with a number of adverse effects (infections, pharyngitis, etc.). The drugs described above alleviate the symptoms of autoimmune diseases and sometimes slow down their progression, but cannot eliminate their cause ensuring only temporary remission.

\section{Blockade of cell response}

At the cell level, autoimmunity can be suppressed by the MA that specifically recognize unique receptors marking certain cell populations (CD2, CD3, CD4, CD8, CD19, CD20, and CD22). This treatment strategy, however, leads to the inhibition of the entire subpopulation of lymphocytes, affects healthy cells and causes serious immune suppression.

\section{CD3}

The MA against CD3 perform well in the mouse models of autoimmune diseases, including autoimmune encephalitis, TNP-KLH-induced colitis, and collagen-induced arthritis. The therapeutic effect of these antibodies can be explained by a few different yet noncontradictory mechanisms. Anti-CD3 MA bind to the $\xi$-subunit of CD3, and the entire CD3-complex is then internalized or blocked. As a result, the T cell temporarily stops to respond to antigens presented to it. Anti-CD3 antibodies are also reported to cause apoptosis of activated T cells [15].

Teplizumab and otelixizumab (ChAglyCD3) are another pair of antibodies against CD3. They are capable of halting (not permanently, though) the death of insulin-producing $\beta$-cells in patients with type I diabetes [16]. Currently, teplizumab is undergoing a phase III clinical trial (TrialNet) that has recruited over 500 patients with stage 2 of diabetes.

\section{Nondepleting antibodies against CD4 and CD8}

A few research works have been published recently on the use of nondepleting monoclonal antibodies against the coreceptors CD4 and CD8. The efficacy of the drugs has been demonstrated in mice with experimentally induced type 1 diabetes [17]. The mechanism of their action is based on the specific interaction with surface receptors of lymphocytes that prevents activation of the immune response. Cell depletion does not occur because the Fc-fragment of MA is unable to bind the Fc-receptor of the recipient and, therefore, does not cause cell death. The mice who received nondepleting MA went into long-term remission (over 20 days) characterized by the reduction in the hyperproduction of IL2 and IFNy.

\section{Anti-CD20}

An anti-CD20 MA known as rituximab (Mabthera) has turned to be highly effective against some autoimmune diseases, such as autoimmune vasculitis, antiphospholipid syndrome, myasthenia gravis, RA, SLE, and multiple sclerosis. The therapeutic effect of the drug is based on the depletion of $B$ cells and lasts for 6 months. In many patients, the response to rituximab is delayed: it is often registered a few months after the intravenous infusion of the drug. A few possible explanations have been proposed: 1) the rate of B-cell clearance from the body varies from patient to patient; 2) the half-life of a plasma cell can affect the rate of response because the cell does not carry CD20 on its surface and keeps secreting antibodies; 3) in some patients even low concentrations of autoimmune antibodies can trigger pathology, delaying response to therapy until the antibodies are cleared from the body. The efficacy of rituximab is comparable or higher than that of immunosuppressants, such as cyclophosphamide, azathioprine, etc. However, rituximab ensures long term remission in as few as $20 \%$ of patients. Among the adverse reactions accompanying the rituximab-based regimens are sensitivity to infection, hypogammaglobulinemia and neutropenia [18, 19]. In the studies mentioned above rituximab was prescribed to patients with severe RA whose conventional treatment with glucocorticoids and cytotoxic agents had failed. It is likely that rituximab not only induces depletion of $\mathrm{B}$ lymphocytes, but also leads to the elimination of $\mathrm{CD}_{20^{+}}$-Th17-effector cells whose proportion is quite high in the blood of patients with RA, which explains the therapeutic effect of the drug [20]. Another possible mechanism exploited by the anti-CD20 therapy is associated with active production of IL6 by B cells: IL6 stimulates the differentiation of T-cell precursors into Th17 and inhibits their conversion into Tregs $[21,22]$. Another humanized anti-CD20 antibody known by the name of ocrelizumab has successfully completed its clinical trials and is now approved by FDA for the treatment of multiple sclerosis; it reduces the number of lesions and slows down the progression of the disease [23]. 


\section{Immune therapy: reprogramming T cells into Tregs}

Tregs ensure immune tolerance in the peripheral organs by attenuating the immune response and bringing autoimmune reactions to a halt [24]. Tregs secrete anti-inflammatory cytokines IL10, TGF $\beta$, and IL35, activate granzyme/perforin pathways mediating the apoptosis of effector cells, and inhibit dendritic cell functions. On the one hand, attempts to intentionally elevate the blood levels of Tregs or stimulate hyperproduction of suppressor cytokines can be regarded as an approach to treating autoimmune diseases. On the other hand, hyperactivity of Tregs leads to the suppression of the immune response and promotes malignancy. A new drug tregalizumab based on nondepleting MA was tested in 2016; it binds the unique epitope on the CD4 molecule, causing CD4+lymphocytes to differentiate into Treg cells.

We believe that combination therapy should be a preferred treatment modality in patients with autoimmune disorders. Such therapy should include the targeted elimination of T- or B-cell clones associated with autoimmunity. The treatment regimen can be based on the consecutive administration of several biologics that target different components of the immune response. For example, cytokine inhibitors and depleting MA can be used as a first-line therapy, as proposed recently. The second-line therapy could include inhibitors of CD28 costimulation mediators or of homeostatic cytokines [25]. Recent studies have demonstrated that inhibition of homeostatic cytokines such as IL15 or IL7 can be a promising approach to the therapy of autoimmune diseases [26].

\section{References}

1. Danke NA, Koelle DM, Yee C, Beheray S, Kwok WW. Autoreactive T cells in healthy individuals. J Immunol. 2004; (172): 5967-2.

2. Konno Y, Kobayashi Y, Takahashi K, Takahashi E, Sakae S, Wakitani M, et al. Fucose content of monoclonal antibodies can be controlled by culture medium osmolality for high antibodydependent cellular cytotoxicity. Cytotechnology. 2012; (64): 249-65.

3. Lai Y, Dong C. Therapeutic antibodies that target inflammatory cytokines in autoimmune diseases. Int Immunol. 2016; (28): 181-8.

4. Nasonov EL, Denisov LN, Stanislav ML. Interleukin-17 is a new target for anti-cytokine therapy of immune inflammatory rheumatic diseases. Rheumatology Science and Practice. 2013; (51): 545.

5. van den Berg WB, Joosten LA, Kollias G, van De Loo FA. Role of tumour necrosis factor alpha in experimental arthritis: separate activity of interleukin 1 beta in chronicity and cartilage destruction. Ann Rheum Dis. 1999; 58 (Suppl 1): 140-8.

6. Dinarello CA, Simon A, van der Meer JWM. Treating inflammation by blocking interleukin-1 in a broad spectrum of diseases. Nat Rev Drug Discov. 2012; (11): 633-52.

7. Ruperto N, Brunner HI, Quartier P, Constantin T, Wulffraat NM, Horneff $G$, et al. Canakinumab in patients with systemic juvenile idiopathic arthritis and active systemic features: results from the 5 -year long-term extension of the phase III pivotal trials. Ann Rheum Dis. 2018; (77): 1710-9.

8. Georgiev K, Georgieva M. Pharmacological properties of monoclonal antibodies directed against interleukins. In: Metodiev $\mathrm{K}$, editor. Immunopathology and Immunomodulation. IntechOpen; 2015; p. 261-86. DOl: 10.5772/61774.

9. Goh AXH, Bertin-Maghit $S$, Ping Yeo $S, H o$ AWS, Derks $H$, Mortellaro A, et al. A novel human anti-interleukin-1 $\beta$ neutralizing monoclonal antibody showing in vivo efficacy. MAbs. 2014; (6): 765-73.

10. Gaffen SL, Jain R, Garg AV, Cua DJ. The IL23-IL17 immune axis: from mechanisms to therapeutic testing. Nat Rev Immunol. 2014; (14): 585-600

11. Tabarkiewicz J, Pogoda K, Karczmarczyk A, Pozarowski P, Giannopoulos K. The role of IL17 and Th17 lymphocytes in autoimmune diseases. Arch Immunol Ther Exp. 2015; (63): 435-49.
So far, identification of unique markers of autoimmune inflammation remains an unsolved problem. T- and B-cell receptors (TCR, BCR) present on the surface of autoreactive lymphocytes can serve as such markers. The search for pathology-associated receptors can start from the sequencing of TCR and BCR repertoires of peripheral blood lymphocytes, as well as of lymphocytes isolated from the sites of inflammation, followed by the comparative analysis of TCR and BCR repertoires of healthy donors and disease-stricken individuals. Today, we know the structure of TCR potentially implicated in the celiac disease and ankylosing spondylitis [27-29]. Our team has established the structure of TCR associated with ankylosing spondylitis [28]; our findings were independently confirmed by our British colleagues [29]. We showed that the pathological T-cell clone carries a variable gene segment TRBV9 and synthesized MA that specifically bind and deplete $T$ cells carrying the TCR associated with ankylosing spondylitis in vitro [30]. The described approach to designing novel therapeutic agents and the MA we synthesized may be a good platform for the development of drugs against autoimmune disorders in general and ankylosing spondilitis in particular.

\section{CONCLUSIONS}

Massive sequencing of immune repertoires of healthy donors and patients with severe autoimmune disorders, including multiple sclerosis and type 1 diabetes, followed by HLA-typing paves the way to the identification of new targets for immune therapies.
12. Lee GR. The Balance of Th17 versus Treg Cells in Autoimmunity. Int J Mol Sci. 2018; 19 (3): 730. DOI:10.3390/ijms19030730.

13. Kikuchi J, Hashizume M, Kaneko Y, Yoshimoto K. Nishina N, Takeuchi T. Peripheral blood CD4(+)CD25(+)CD127(low) regulatory $T$ cells are significantly increased by tocilizumab treatment in patients with rheumatoid arthritis: increase in regulatory $T$ cells correlates with clinical response. Arthritis Res Ther. 2015; (17): 10.

14. Lal G, Zhang N, van der Touw W, Ding Y, Ju W, Bottinger EP, et al. Epigenetic regulation of Foxp3 expression in regulatory $T$ cells by DNA methylation. J Immunol. 2009; (182): 259-73.

15. Kuhn C, Weiner HL. Therapeutic anti-CD3 monoclonal antibodies: from bench to bedside. Immunotherapy. 2016; (8): 889-906.

16. Guglielmi C, Williams SR, Del Toro R, Pozzilli P. Efficacy and safety of otelixizumab use in new-onset type 1 diabetes mellitus. Expert Opin Biol Ther. 2016; (16): 841-6.

17. Yi Z, Diz R, Martin AJ, Morillon YM, Kline DE, Li L et al. Long-term remission of diabetes in NOD mice is induced by nondepleting anti-CD4 and anti-CD8 antibodies. Diabetes. 2012; (61): 2871-80.

18. Randall KL. Rituximab in autoimmune diseases. Aust Prescr. 2016; (39): 131-4.

19. Looney RJ. B cells as a therapeutic target in autoimmune diseases other than rheumatoid arthritis. Rheumatology. 2005; 44 (Suppl 2): ii13-ii17.

20. Mélet J, Mulleman D, Goupille P, Ribourtout B, Watier $H$, Thibault G. Rituximab-induced $T$ cell depletion in patients with rheumatoid arthritis: association with clinical response. Arthritis Rheum. 2013; (65): 2783-90.

21. Barr TA, Shen P, Brown S, Lampropoulou V. B cell depletion therapy ameliorates autoimmune disease through ablation of IL-6-producing B cells. J Exp Med. 2012; 209 (5): 1001-10. DOI: 10.1084/jem.20111675.

22. Korn T, Mitsdoerffer M, Croxford AL, Awasthi A, Dardalhon VA, Galileos $\mathrm{G}$ et al. IL6 controls Th17 immunity in vivo by inhibiting the conversion of conventional $\mathrm{T}$ cells into Foxp3+ regulatory $\mathrm{T}$ cells. Proc Natl Acad Sci USA. 2008; (105): 18460-5.

23. Mulero P, Midaglia L, Montalban X. Ocrelizumab: a new milestone 
in multiple sclerosis therapy. Ther Adv Neurol Disord. 2018; (11): 1756286418773025. DOI: 10.1177/1756286418773025.

24. König $M$, Rharbaoui $F$, Aigner $S$, Dälken $B$, Schüttrumpf J. Tregalizumab - A Monoclonal Antibody to Target Regulatory T Cells. Front Immunol. 2016; (7): 11.

25. Smilek DE, Ehlers MR, Nepom GT. Restoring the balance: immunotherapeutic combinations for autoimmune disease. Dis Model Mech. 2014; (7): 503-13.

26. Chen $Y$, Chauhan SK, Tan X, Dana R. Interleukin-7 and -15 maintain pathogenic memory Th17 cells in autoimmunity. J Autoimmun. 2017; (77): 96-103.

27. Yohannes DA, Freitag TL, de Kauwe A, Kaukinen K, Kurppa K, Wacklin $\mathrm{P}$ et al. Deep sequencing of blood and gut T-cell receptor $\beta$-chains reveals gluten-induced immune signatures in celiac disease. Sci Rep. 2017; (7): 17977.
28. Komech EA, Pogorelyy MV, Egorov ES, Britanova OV, Rebrikov DV, Bochkova AG et al. CD8 ${ }^{+} T$ cells with characteristic $T$ cell receptor beta motif are detected in blood and expanded in synovial fluid of ankylosing spondylitis patients. Rheumatology. 2018; (57): 1097104.

29. Faham M, Carlton V, Moorhead M, Zheng J, Klinger M, Pepin F et al. Discovery of T Cell Receptor $\beta$ Motifs Specific to HLA--B27-Positive Ankylosing Spondylitis by Deep Repertoire Sequence Analysis. Arthritis \& Rheumatology. Wiley Online Library; 2017; (69): $774-84$

30. Israelson MA, Stepanov AV, Staroverov DB, Shagina IA, Misorin AK, Evstratieva AV, Merzlyak EM, Bogdanova EA, Britanova OV, Lukyanov SA. Testing of monoclonal antibodies against the T-cell receptor associated with ankylosing spondylitis. Bulletin of RSMU. 2018; (5): 71-9. DOI: 10.24075/brsmu.2018.064.

\section{Литература}

1. Danke NA, Koelle DM, Yee C, Beheray S, Kwok WW. Autoreactive T cells in healthy individuals. J Immunol. 2004; (172): 5967-2.

2. Konno Y, Kobayashi Y, Takahashi K, Takahashi E, Sakae S, Wakitani $\mathrm{M}$, et al. Fucose content of monoclonal antibodies can be controlled by culture medium osmolality for high antibodydependent cellular cytotoxicity. Cytotechnology. 2012; (64): 249-65.

3. Lai $Y$, Dong C. Therapeutic antibodies that target inflammatory cytokines in autoimmune diseases. Int Immunol. 2016; (28): 181-8.

4. Nasonov EL, Denisov LN, Stanislav ML. Interleukin-17 is a new target for anti-cytokine therapy of immune inflammatory rheumatic diseases. Rheumatology Science and Practice. 2013; (51): 545.

5. van den Berg WB, Joosten LA, Kollias G, van De Loo FA. Role of tumour necrosis factor alpha in experimental arthritis: separate activity of interleukin 1 beta in chronicity and cartilage destruction. Ann Rheum Dis. 1999; 58 (Suppl 1): 140-8.

6. Dinarello CA, Simon A, van der Meer JWM. Treating inflammation by blocking interleukin-1 in a broad spectrum of diseases. Nat Rev Drug Discov. 2012; (11): 633-52.

7. Ruperto N, Brunner HI, Quartier P, Constantin T, Wulffraat NM, Horneff $\mathrm{G}$, et al. Canakinumab in patients with systemic juvenile idiopathic arthritis and active systemic features: results from the 5 -year long-term extension of the phase III pivotal trials. Ann Rheum Dis. 2018; (77): 1710-9.

8. Georgiev K, Georgieva M. Pharmacological properties of monoclonal antibodies directed against interleukins. In: Metodiev $\mathrm{K}$, editor. Immunopathology and Immunomodulation. IntechOpen; 2015; p. 261-86. DOI: 10.5772/61774.

9. Goh $A X H$, Bertin-Maghit $S$, Ping Yeo $S$, Ho AWS, Derks $H$, Mortellaro $A$, et al. A novel human anti-interleukin- $1 \beta$ neutralizing monoclonal antibody showing in vivo efficacy. MAbs. 2014; (6): 765-73.

10. Gaffen SL, Jain R, Garg AV, Cua DJ. The IL23-IL17 immune axis: from mechanisms to therapeutic testing. Nat Rev Immunol. 2014; (14): 585-600.

11. Tabarkiewicz J, Pogoda K, Karczmarczyk A, Pozarowski P, Giannopoulos K. The role of IL17 and Th17 lymphocytes in autoimmune diseases. Arch Immunol Ther Exp. 2015; (63): 435-49.

12. Lee GR. The Balance of Th17 versus Treg Cells in Autoimmunity. Int J Mol Sci. 2018; 19 (3): 730. DOI:10.3390/ijms19030730.

13. Kikuchi J, Hashizume M, Kaneko $Y$, Yoshimoto $K$, Nishina $N$ Takeuchi T. Peripheral blood CD4(+)CD25(+)CD127(low) regulatory $T$ cells are significantly increased by tocilizumab treatment in patients with rheumatoid arthritis: increase in regulatory $T$ cells correlates with clinical response. Arthritis Res Ther. 2015; (17): 10.

14. Lal G, Zhang N, van der Touw W, Ding Y, Ju W, Bottinger EP, et al. Epigenetic regulation of Foxp3 expression in regulatory $T$ cells by DNA methylation. J Immunol. 2009; (182): 259-73.

15. Kuhn C, Weiner HL. Therapeutic anti-CD3 monoclonal antibodies: from bench to bedside. Immunotherapy. 2016; (8): 889-906.

16. Guglielmi C, Williams SR, Del Toro R, Pozzilli P. Efficacy and safety of otelixizumab use in new-onset type 1 diabetes mellitus. Expert Opin Biol Ther. 2016; (16): 841-6.
17. Yi Z, Diz R, Martin AJ, Morillon YM, Kline DE, Li L et al. Long-term remission of diabetes in NOD mice is induced by nondepleting anti-CD4 and anti-CD8 antibodies. Diabetes. 2012; (61): 2871-80.

18. Randall KL. Rituximab in autoimmune diseases. Aust Prescr. 2016; (39): 131-4.

19. Looney RJ. B cells as a therapeutic target in autoimmune diseases other than rheumatoid arthritis. Rheumatology. 2005; 44 (Suppl 2): ii13-ii17.

20. Mélet J, Mulleman D, Goupille P, Ribourtout B, Watier H, Thibault G. Rituximab-induced T cell depletion in patients with rheumatoid arthritis: association with clinical response. Arthritis Rheum. 2013; (65): 2783-90.

21. Barr TA, Shen P, Brown S, Lampropoulou V. B cell depletion therapy ameliorates autoimmune disease through ablation of IL-6-producing B cells. J Exp Med. 2012; 209 (5): 1001-10. DOI: 10.1084/jem.20111675.

22. Korn T, Mitsdoerffer M, Croxford AL, Awasthi A, Dardalhon VA, Galileos $G$ et al. IL6 controls Th17 immunity in vivo by inhibiting the conversion of conventional T cells into Foxp3+ regulatory $T$ cells. Proc Natl Acad Sci USA. 2008; (105): 18460-5.

23. Mulero P, Midaglia L, Montalban X. Ocrelizumab: a new milestone in multiple sclerosis therapy. Ther Adv Neurol Disord. 2018; (11): 1756286418773025. DOI: 10.1177/1756286418773025.

24. König $M$, Rharbaoui $F$, Aigner $S$, Dälken $B$, Schüttrumpf J. Tregalizumab - A Monoclonal Antibody to Target Regulatory $T$ Cells. Front Immunol. 2016; (7): 11

25. Smilek DE, Ehlers MR, Nepom GT. Restoring the balance: immunotherapeutic combinations for autoimmune disease. Dis Model Mech. 2014; (7): 503-13.

26. Chen $Y$, Chauhan SK, Tan X, Dana R. Interleukin-7 and -15 maintain pathogenic memory Th17 cells in autoimmunity. J Autoimmun. 2017; (77): 96-103.

27. Yohannes DA, Freitag TL, de Kauwe A, Kaukinen K, Kurppa K, Wacklin P et al. Deep sequencing of blood and gut T-cell receptor $\beta$-chains reveals gluten-induced immune signatures in celiac disease. Sci Rep. 2017; (7): 17977.

28. Komech EA, Pogorelyy MV, Egorov ES, Britanova OV, Rebrikov DV, Bochkova AG et al. CD8 ${ }^{+} T$ cells with characteristic T cell receptor beta motif are detected in blood and expanded in synovial fluid of ankylosing spondylitis patients. Rheumatology. 2018; (57): 1097 104.

29. Faham M, Carlton V, Moorhead M, Zheng J, Klinger M, Pepin F et al. Discovery of T Cell Receptor $\beta$ Motifs Specific to HLA--B27-Positive Ankylosing Spondylitis by Deep Repertoire Sequence Analysis. Arthritis \& Rheumatology. Wiley Online Library; 2017; (69): 774-84.

30. Израельсон М. А., Степанов А. В., Староверов Д. Б., Шагина И. А., Мисорин А. К., Евстратьева А. В. и др. Тестирование моноклональных антител к Т-клеточному рецептору, ассоциированному с анкилозирующим спондилитом. Вестник РГМУ. 2018; (5): 83-92. DOI: 10.24075/vrgmu.2018.064. 


\title{
CHIMERIC ANTIGEN RECEPTOR EXPRESSION IN NATURAL KILLER CELL LINE NK-92 BY TRANSDUCTION WITH LENTIVIRAL PARTICLES PSEUDOTYPED WITH THE SURFACE GLYCOPROTEINS OF THE MEASLES VIRUS VACCINE STRAIN
}

\author{
Kravchenko YE, Gagarinskaya DI, Frolova El, Chumakov SP $\bowtie$ \\ Shemyakin-Ovchinnikov Institute of Bioorganic Chemistry of the Russian Academy of Sciences, Moscow
}

\begin{abstract}
Cancer immunotherapy with T-cells that carry chimeric antigen receptors is currently on cutting edge of modern oncology. Autotransplantation of T-lymphocytes with chimeric receptor specific for certain tumor antigen proves to be clinically effective, but costly. Linear carriers of chimeric antigen receptors based on natural killer NK-92 cell culture may be an affordable alternative, however, this culture is resistant to lentiviral transduction. Recently, lentiviral vectors, pseudotyped with surface glycoproteins of the measles virus vaccine strain, have recently been successfully applied for transduction of primary immune cells. The aim of the work was to assess the efficiency of transduction of NK-92 cells with lentivirus vectors, pseudotyped with measles $\mathrm{F}$ and $\mathrm{H}$ surface glycoproteins, as well as to establish optimal conditions for selection of NK-92 transduced with the chimeric receptor against CD20 and to evaluate the culture's cytotoxic potential. The results showed that the maximum infectious titer is achieved using the $\mathrm{H} \triangle 18$ variant in combination with $\mathrm{F} \triangle 30$, and the use of the TBK1/IKKE inhibitor BX795 results in additional 3-fold increase in the infectious titer. CAR-expressing NK-92 were able to suppress the proliferation of CD20+ cell line Raji in lower effector-to-target ratios than unmodified NK-92.
\end{abstract}

Keywords: cellular immunotherapy, chimeric antigen receptors, CAR, lentiviral vectors, natural killer cells, linear cellular carriers, pseudotyping with measles glycoproteins

Funding: this work was funded by MESR (project code RFMEFI60716X0156).

$\varangle$ Correspondence should be addressed: Stepan P. Chumakov Miklukho-Maklaya 16/10, Moscow, 117997; hathkul@gmail.com

Received: 27.11.2018 Accepted: 20.12.2018

DOI: $10.24075 /$ brsmu.2018.091

\section{ЭКСПРЕССИЯ ХИМЕРНОГО АНТИГЕННОГО РЕЦЕПТОРА В НАТУРАЛЬНЫХ КИЛЛЕРАХ ЛИНИИ NК-92 ПУТЕМ ТРАНСДУКЦИИ ЛЕНТИВИРУСНЫМИ ЧАСТИЦАМИ, ПСЕВДОТИПИРОВАННЫМИ ПОВЕРХНОСТНЫМИ ГЛИКОПРОТЕИНАМИ ВАКЦИННОГО ШТАММА ВИРУСА КОРИ}

\author{
Ю. Е. Кравченко, Д. И. Гагаринская, Е. И. Фролова, С. П. Чумаков \\ Институт биоорганической химии имени М. М. Шемякина и Ю. А. Овчинникова РАН, Москва
}

\begin{abstract}
Клеточная иммунотерапия с использованием химерных антигенных рецепторов (ХАР) является одним из перспективных направлений развития современной онкологии. Собственные Т-лимфоциты пациента с приданной специфичностью в отношении неоантигенов опухолей за счет экспрессии ХАР демонстрируют клиническую эффективность, однако стоимость такой терапии чрезвычайно высока. В качестве более доступной альтернативы могут быть использованы унифицированные носители ХАР на основе линии клеток натуральных киллеров NK-92. Эта культура отличается устойчивостью к лентивирусной трансдукции; однако для трансдукции первичных иммунных клеток недавно начали успешно применять лентивирусные векторы, псевдотипированные поверхностными гликопротеинами вакцинного штамма вируса кори. Целью работы было определить эффективность трансдукции клеток NK-92 лентивирусами, псевдотипированными гликопротеинами F и H вируса кори, а также условия селекции NK-92, трансдуцированных химерным рецептором против CD20, и оценить их цитотоксическое действие. Результаты исследования показали, что максимальный трансфекционный титр достигается при использовании варианта белка H (H $\triangle 18)$ в сочетании с вариантом белка F (FA30), а применение BX795 (ингибитора TBK1/IKKع) дополнительно позволяет добиться трехкратного увеличения инфекционного титра. ХАР-экспрессирующие клетки NK-92 оказались способными подавлять пролиферацию CD20+-клеток линии Raji в меньшей дозе, по сравнению с немодифицированными клетками NK-92.
\end{abstract}

Ключевые слова: клеточная иммунотерапия, химерные антигенные рецепторы, ХАР, лентивирусные векторы, натуральные киллеры, линейные клеточные носители, псевдотипирование, гликопротеины кори

Финансирование: работа выполнена при финансовой поддержке Министерства образования и науки РФ, уникальный код проекта RFMEFI60716X0156.

$\bowtie$ Для корреспонденции: Степан Петрович Чумаков

ул. Миклухо-Маклая, 16/10, г. Москва, 117997; hathkul@gmail.com

Статья получена: 27.11.2018 Статья принята к печати: 20.12.2018

DOI: $10.24075 /$ vrgmu.2018.091 